\title{
Educators and public librarians: unwitting partners in the information literacy education of South African youth?
}

\section{Genevieve Hart}

\section{Genevieve Hart}

Department of Library and Information Science

University of the Western Cape

ghart@uwc.ac.za

\section{Abstract}

The article reports on a study of the capacity of public librarians in South Africa for information literacy education. The first phase explores the conceptions of public library staff of their role in information literacy education. The second phase comprises a participant observation case study in two public libraries and interviews with teachers. The public librarians are found to have rather limited conceptions of information literacy. They tend to see their role as the provision of resources for projects on demand and the prevailing information literacy education is once-off library orientation. The teachers are positive about the role of libraries and are unanimous that the new curriculum means that children need access to more resources. Closer probing reveals that they make very little use of libraries in their personal and professional lives. They lack cognizance of the role of librarians in information literacy education and, in common with the public librarians, tend to see libraries as warehouses where their pupils are sent to "fetch" resources. Both groups see information as "something" that is stored and given out - rather than a subjective sense-making process. Paradoxically, these shared conceptions contribute to a gulf between the two sectors, which needs to be bridged if the needs of school learners are to be met.

\section{Introduction}

This article argues that public librarians in South Africa are closely involved in the school curriculum, but their role is misunderstood and underestimated by educationists. The specific focus is educators' and public librarians' conceptions of the role of the library in education. 
The article makes no attempt to provide a rigorous account of the whole research project - a two phase mixed methods study of the readiness of South African public libraries for information literacy education. The intention is rather to air findings of specific interest to educationists. Its focus at first is on public librarians' conceptions of their role in information literacy education; it then moves to the second phase with a focus on educators' conceptions of the educational role of the public library. The suggestion is that, paradoxically, shared conceptions contribute to a gulf between the two sectors, which needs to be bridged if the needs of school learners are to be met.

The following short vignette might illustrate what these needs are. It describes an incident in the second phase of the study, a participant observation study in the two public libraries of a small South African town, and serves to highlight questions on the "connections" between public libraries and schools.

Learners' information-seeking behaviours: a vignette of an incident in Woodsville Library

Woodsville Library, Friday 22 October 2004 (Names are pseudonyms) It is $2.30 \mathrm{pm}$ in Woodsville Library. Every nook and cranny is crammed with bodies. It is very noisy and the two library staff frequently call out: "Hey Guys! This is a library! Keep it quieter!” Tenji Miti, the Library Assistant, approaches me with a girl she has been talking to near the photocopier, where there is a long line of school learners waiting for her to copy pages.

$\mathrm{GH} \quad$ What do you need to do?

Learner It's for Afrikaans. I have to write a paragraph for Afrikaans on an illness. And I must have pictures.

I shepherd her to the medical books in the children's section just behind the copier - hoping to find a juvenile book on illnesses in Afrikaans.

GH Which illness?

Learner Which illness can I do?

She shows me a piece of paper with some words scribbled - hoes [cough], maagpyn [stomach pain], tuberkole [tuberculosis], bors-kanker [ breast cancer].

GH Which are you interested in? Maybe you already know something about one?

Silence from the learner. She stands looking unhappy. I guess that she wants to be "given" an illness. Seeing no easy book in Afrikaans on the shelves, I take her to the standard Afrikaans encyclopaedia set Kennis and pull down the Index volume. She hangs back so I open it up at "T" for Tuberkole and show her the reference to Volume 26 page 161. Still she hangs back so I show her that volume. Still she waits so I pull it down and open it up at page 161. I see an article, well-laid out with several pictures and diagrams. The learner glances at the pages and mutters something. 
GH What do you want to find out about the illness?

The learner looks blank. I wait for what seems a longish time but then find myself continuing.

GH How about - "What is TB?" "What causes it?" "How do you know you have it - its symptoms?" "And then maybe, how it is treated?"

Look - it's all here under these headings. Why don't you read this and take what you need. The Afrikaans is easy, there are lots of pictures, and you won't have to translate from English.

I now withdraw. A few minutes later I see her at the photocopier - Tenji is copying an article from World book encyclopaedia for her. The Kennis volume is lying on the table.

The vignette raises certain questions, for example over:

- the prior learning and preparation of the students in the classroom before coming into the public library

- the role of educators. Are they aware of their learners' problems in completing their assignments in the library?

- the responsibility of the public librarian regarding the information literacy education of school learners. Is it to provide a page or two to copy which seems to be the expectation of the learners themselves? Or, given the probable absence of library programmes in their schools, is it to intervene more positively in their education and to contribute to their lifelong learning competencies?

\section{Background}

Since the late 1990s, the author has explored the impact of curricular change in South Africa on school and public libraries (Hart 2000; 2003; 2004). The research in both schools and libraries has examined different angles but is aimed at understanding the contradiction between the promise inherent in the transformed curriculum of a favourable climate for libraries and the reality, widely documented in the professional literature (Leach 1998; Lor 1998; Karlsson 2003), that both school and public libraries have lost ground. Less than $20 \%$ of South African schools have libraries (South Africa. Department of Education, 1999; Bot, 2005); school library policy-making at national level has been a slow and discontinuous process (Karlsson 2003); and public libraries have been subjected to what Lor, then Director of the National Library of South Africa, described in 1998 as “crippling budget cuts”.

A curriculum, in theory at least, reflects a society's beliefs about its requirements of its school-leavers, about knowledge, and about the needs of its learners (Doiron 1999). The optimism among librarians in the late 1990s that Curriculum 
2005 was "library friendly" (for example Zinn 2001) rested on both its ethos and its pedagogies. Its documentation recognised the need for information skills, with the skills of finding, assessing and using information listed as a generic cross-curricular outcome. Information literacy is moreover implied in several of the other desired learning outcomes. The Revised National Curriculum Statement retains these outcomes - stating that South Africa needs adaptable, curious learners who are trained to think critically and solve problems and who are able to compete in the global economy of the information society (South Africa. Department of Education 2002).

The pedagogies of the new South African curriculum reflect international recognition that the information society demands different classroom approaches. The information or knowledge economy prizes self-educators, people who, in Fritjof Capra's words, can "process information and create knowledge" (2003: 125). Adaptable independent lifelong learners need to learn how to learn at school since what they learn will soon be outdated. A perusal of the international literature of educational change over the past two decades reveals shifts away from teacher-centred approaches towards the more constructivist approaches evident in South Africa (Fullan 1991; Marsh and Morris 1991). Today, learners are expected to build their own knowledge through engaging with a wide range of resources. The emphasis in assessment of learning is on projects and portfolios of work rather than on rote memorising from textbooks and teachers' notes. Librarians have been quick to point out the implications of these moves - seeing them in terms of "resource-based learning" (Metcalfe, 1994; Lombo, 2002). Such approaches demand high level cognitive skills, such as the ability to analyse a topic, read "around" a topic, identify what information is needed, formulate useful questions to guide the informationseeking, find and evaluate information, analyse and interpret texts of various kinds, apply information to solve the problem, and, so on. In recent years, the constructs of information literacy and information literacy education have come to encapsulate these high-level skills and have been adopted by professional school library associations across the world as the fundamental mission of school libraries (American Association of School Librarians and Association for Educational Communications and Technology 1998; Australian School Library Association 2001).

Current thinking defines the construct of information literacy education as learning how to find and use information to build new knowledge. The research literature of information literacy has its roots in two traditions - cognitive information science and cognitive learning theory. Unlike its predecessors, media studies or book education, information literacy education is embedded in the classroom learning programme. Children learn information skills most effectively as they engage in their assignments and projects (Turner, 1991; 
Todd, 1995b). Of course this thinking provides challenges for public librarians, who cannot assume the day to day contact with educators and learners that school librarians might.

Some research has documented the increase in project work in South African schools and its impact on public libraries (Hart 2000; 2003; Maepa and Mhinga, 2003). Project work implies access to learning and information resources and, in the absence of libraries inside their schools, learners flock to public libraries in the afternoons in search of these resources. For example, in 2002 a study within the two public libraries in a disadvantaged township in Cape Town, involving interviews with 900 learners over four consecutive afternoons, revealed that $62 \%$ of them were in the library that day to "do a project", "sit and do my homework" or "use library books to do an assignment”. Only 3\% reported access to a school library (Hart 2004). This quantitative study made no comment on the quality of the learning experience in the two public libraries - merely noting the unmanageably large numbers and the long queues of children at the photocopiers. It also documented the frustration of the library staff as revealed in their comments on the challenges of working with learners inadequately prepared for their assignments. Maepa and Mhinga's study of school learners' use of a rural public library in Limpopo (2003) echoes some of the comments made by the Cape Town library staff on the inappropriateness of many of the topics given by educators and on learners' lack of preparedness for their library assignments - which demand high-level analytic and interpretive skills.

There is evidence in the literature of school librarianship internationally of the dependence of school libraries on educators' “attitudes”. A recent study of 531 teachers in Mississippi, for example, found that teachers' personal attitudes to librarians strongly influence the effectiveness of school library programmes (Roberson, Applin and Schweinle 2004). Certain teaching styles and accompanying beliefs about learning within a school have been shown to be a prerequisite for the success of school library programmes (Kuhlthau 1993; Todd and Kuhlthau 2005). Other studies, including one or two in South Africa, do not explicitly focus on the physical facility of a school library or a library programme but explore underlying subjective factors which are deemed to impact on use of the school library. For example, they examine links between teachers' beliefs about learning on one hand and, on the other, educators' information literacy, their attitudes to information literacy education and their use of learning resources (for example Borman 1999; Hara 1999; Hart 1999; Henri 2000). The thinking underlying these studies is encapsulated in Brown's comment (1999:180) on school libraries that: 
To ask teachers to change the materials they use for teaching, and the teaching approaches they use, is to require a change in their basic beliefs about how students learn.

In the South African context, both these strands are of interest to public librarians as well as school librarians since the absence of school libraries means that public libraries might be expected to take on a more directly curricular role. And indeed, as already mentioned, there is growing evidence that South African public libraries are experiencing a strong increase in use by school learners. However, there are questions over the capacity of South African public libraries for an enhanced educational role. Some of these questions concern physical capacity, such as space, staff and resources. But the question highlighted in this article concerns their connections with schools - found elsewhere to be crucial to effective information literacy education in public libraries (Bundy 2002). Thus: Do public libraries have the connections with schools that an enhanced role in information literacy education implies? Is there recognition amongst public library staff and educators in schools that information literacy education is a "shared endeavour" (Bundy 2002)?

\section{Research study}

The author's research is an investigation of the role of public libraries in South Africa in the information literacy education of school-going youth. It has two phases - the first, a wide-ranging survey of information literacy education and staff attitudes towards it in Mpumalanga's public libraries, that was undertaken in March/April 2004, and the second, a participant observation study throughout October 2004 in two public libraries in a small rural town, Woodsville (a pseudonym), to the east of Mpumalanga. The second phase case study examined information literacy education in the two libraries more closely. It included visits to the seven schools in or near the town and interviews with their principals and Grade 7 and 8 educators. The aim in the interviews was to explore teachers' use of information resources and their relations with libraries both inside and outside their schools.

The premise of the study is that, in a country where, as mentioned earlier, less than $20 \%$ of schools have functional libraries and where there is a new curriculum that, according to widespread consensus, emphasises resource-based enquiry learning, public libraries might well have to take on a more active role in information literacy education than they might be expected to in countries with better developed school library structures. Of course, the challenge for public librarians is that they do not have day-to-day access to the classroom as school librarians might. Clearly then, the relationships between school and 
public library are crucial to effective information literacy education in public libraries.

\section{Librarians' experience of and conceptions of information literacy education}

It cannot be assumed that Mpumalanga public librarians share the assumptions and perspectives of information literacy theorists or practitioners working in other environments. Therefore, the first-phase survey of public libraries in Mpumalanga set out to explore librarians' experience and conceptions of their role in the curriculum and in information literacy education.

The study confirms the heavy use of public libraries by school learners. There is unanimity among the 57 respondents in the first phase that Curriculum 2005 and its successor, the Revised National Curriculum Statement, have brought about an increase in use by school learners. The survey revealed some ambivalence about this increase and the resulting new pressures on public library staff. Some welcome the changes, seeing an enhanced educational role for the public library as its "ticket to the future". However, others express doubt over whether a more active curricular role should be expected of public libraries. Some of these doubts emanate from concern over capacity - their libraries are short of staff and space. Others are more fundamental - the heavy use of the public library by school learners does not fit their conceptions of the social role of a public library and they fear that it jeopardises their services to other groups in the community. A sample of these comments follows:

Realistically we can't do more. But we do it. We are forced to do it. We don't have enough time and staff - we can only support. (Questionnaire 38)

Because we should not be teachers - our job is just to help them find information. (Questionnaire 7)

But schools don't have teacher-librarians and we have to do it. It shouldn't be our job but for a myriad of reasons it's the reality. (Questionnaire 43)

We have a lot of black kids and first time users - therefore we play a direct role. (Questionnaire 37)

At the moment we are doing it directly but we are not supposed to. We should be serving all groups - not just the schools. (Questionnaire 4) We do experience problems with learners who don't understand that we are only support. They don't understand our stock cannot provide for their needs. (Questionnaire 46) 
These comments and others show agreement that they are now, even if rather reluctantly, directly involved in the learning of their users for the following reasons:

- the children's needs are so urgent that they cannot refuse

- the influx of children from historically disadvantaged schools with little experience of libraries has forced them to rethink their job

- the lack of school libraries and information literacy education in schools has obliged public libraries to step into the gap

- users do not understand that public libraries offer mere support; therefore, staff feel obliged to step into line with their expectations.

A common refrain in the interviews in the first phase was, "We are doing the work of school libraries!" What this "work" entails became one of the central questions of the study and is found to have three components.

Firstly, respondents' afternoons are clearly dominated by the needs of school learners. There is consensus that learners are inadequately prepared for their information-seeking in the library and that public library staff have to intervene on an individual basis - for example in helping learners understand their assignment topics. The second most obvious activity in support of school learning is the provision of learning and information resources - books, photocopies, pamphlets, pages copied from the World Wide Web. Many libraries maintain so-called "project shelves" for materials set aside for current projects. A common complaint among respondents is that they are often caught unawares. A rush of children, all asking for the same information, alerts them to a project and they quickly put materials aside (thus, it must be said, shortcircuiting the learning experience of independent information seeking).

In their descriptions of information literacy and of the processes of school project work, the Mpumalanga public librarians come across as preoccupied with "the library". Most of the 57 respondents describe an information literate person as "knowing how to use a library" or "able to use encyclopaedias and other books in the reference section". Many describe the first step in project work as "asking the librarian" or "knowing where to go in the library". Given these perceptions, it is not surprising that the predominant kind of information literacy education with groups is "library orientation". It comprises once-off sessions, usually at the beginning of the school year or during South Africa's annual Library Week, which instruct school groups in library layout and procedures - with sometimes some demonstration of the use of reference tools. There seems to be little awareness of the evolution of information literacy education from the "book education" that prevailed in South African schools in the 1980s. Such source-based approaches with classes have been found to be ineffective since students do not generalise what they learn to other situations. 
Research has shown that the best information literacy education is embedded in the curriculum - when children learn information skills in the context of their real assignments and projects (Todd 1995a; Kuhlthau 2000; McMillan 2001).

Of course the embedding of their instruction in the day to day learning programme might well be beyond the reach of public librarians, who do not have easy access to the curriculum and whose teaching capacity might well be questionable (Peacock 2001; Clyde 2002). As mentioned above, the aim of the second phase of the study was to build understanding of information literacy education within one site in order to explore the challenges. The pseudonymous town of Woodsville was chosen as a case site partly because, in their interviews in the course of the first phase, the librarians in both of the Woodsville libraries had positive attitudes to their work with schools and reported positive relations with their surrounding schools. Another factor was that that the number of schools served by the two libraries was deemed to be manageable - with each library reporting four schools within its catchment area. (The figure can be compared with the 40 schools reported by a librarian in charge of the only library in one of Mpumalanga’s former “homelands”).

\section{An introduction to Woodsville}

Before turning to the relations between the Woodsville libraries and their schools, perhaps it is necessary to describe the context of the case study. Woodsville has two libraries - one downtown and one in the historically disadvantaged township of Hillside (pseudonym). The two libraries serve seven schools as shown in the following figure.

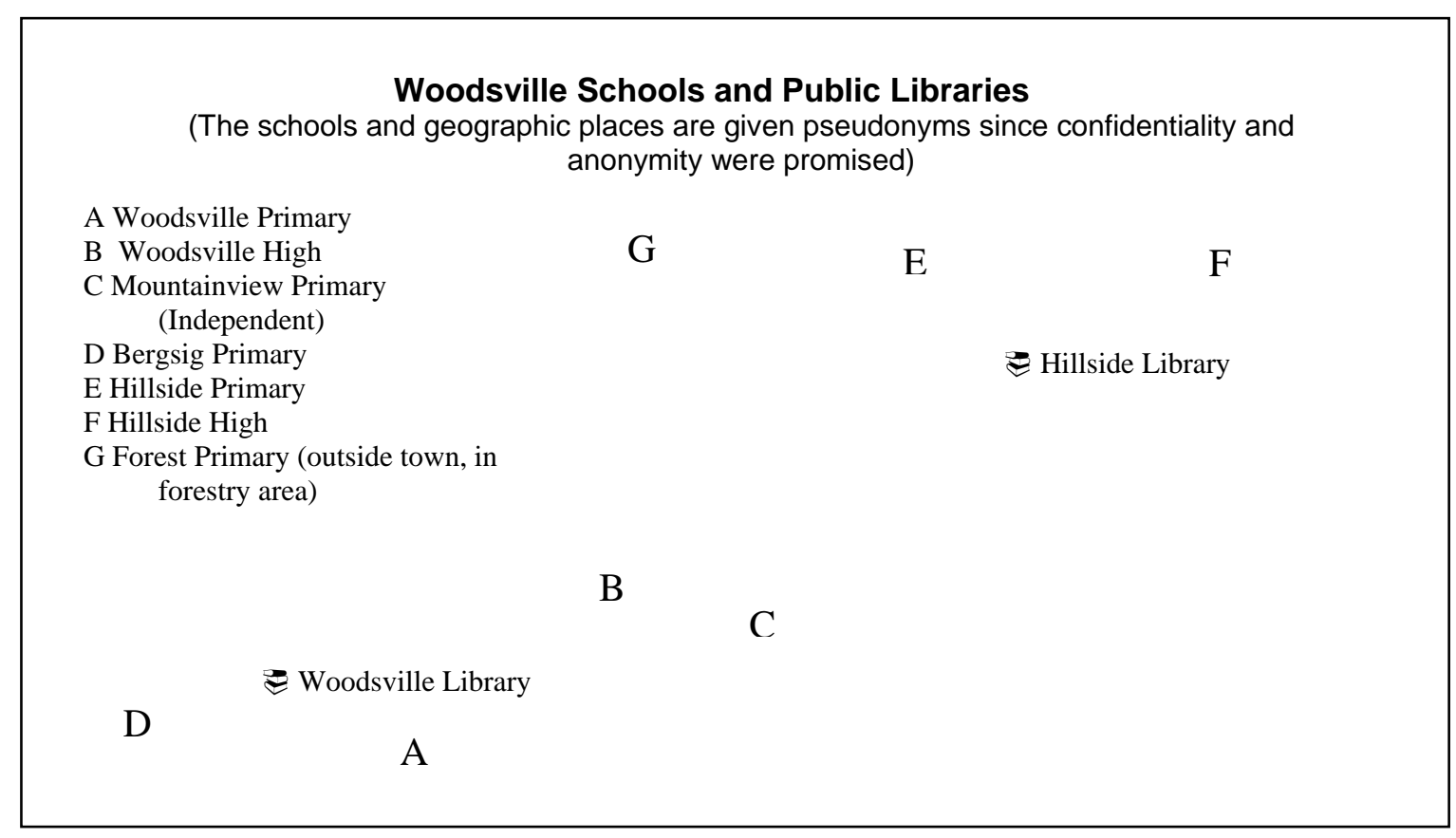


The demise of apartheid education has brought major shifts in patterns of enrolment in the schools, with the formerly exclusively "white" schools in town having had a large intake of disadvantaged learners from the townships and rural areas - since these schools are perceived to be superior. The township schools, as a result, have had to spread their nets wider into rural areas to the north and east in order to maintain their numbers. One result of the changes in their learner bodies is a general shift to English as the language of learning as the schools respond to the new dispensation and compete for learner numbers. The two historically white Afrikaans medium schools in town now have a stream of English medium classes - for African children, largely, it seems. Bergsig, the area designated for Afrikaans speaking "Coloured" people in the 1980s, now has an informal settlement of Zulu-speaking people. The result is that Bergsig Primary School has now switched to English as its language of learning. The schools in the Hillside Township, whose learners are largely (although not exclusively) SiSwati-speaking, now have English as their language of learning. Overall, the implication of these shifts is that most children are being taught in a language that is not their home language. Although the learner bodies of the schools might now be described as multicultural, their teacher cohorts have not changed, as both principals in the two Woodsville schools acknowledge. Thus all the educators in the study from the historically white schools in the centre of Woodsville are white and all those from the township schools are black.

Only one of the schools has a functioning library, Woodsville Primary. However, some might well question the description of this library as "functional" since its "librarian" is in fact a fulltime Grade Four teacher. The library is considered to be her extramural activity and she opens it at intervals and on two afternoons a week for one hour. At present, none of the schools provides Internet access to its students. A few years ago, the two historically advantaged schools in town closed their libraries, having lost their teacherlibrarian posts when national teacher/pupil ratios were enforced to redress apartheid era inequalities. The two principals report that they had believed that computer rooms with Internet access could replace them. Interviews with the schools' educators uncover some rethinking of this decision. Apparently, their computer rooms are occupied by computer classes for most of the day and Internet connectivity has proved difficult to sustain.

The significance of the virtual absence of school libraries for the Woodsville public libraries is twofold:

- it explains the heavy use of the Woodsville public libraries by school learners

- it implies that learners are not being taught at school how to use a library and its resources - and perhaps the broader information skills of information literacy. 
Another factor became evident in the course of the school visits. Mini-bus taxis transport large numbers of children from rural areas to the schools each day. Immediately, on the close of the school day, they line up outside the schools to take them home to rural areas, where there are no public libraries. These are children who can be assumed to have no Internet access at home and whose parents might well be insufficiently educated to support school project work.

\section{"Don't they know how important it is?"}

The heading above is the plaintively rhetorical question asked by the Woodsville Librarian, Tara Botha (pseudonym), at the end of the first week of the case study. The question reflects her frustration with the Hillside Primary School's educators after the failure of an information literacy project of which she had had high expectations. On the author's arrival at Woodsville, Tara Botha had commented that she came at an "excellent" time since she was to repeat the project which she had undertaken with Bergsig Primary the previous term and which had been a success. But on the third morning of the case study, the group of Grade 7 learners from Hillside Primary failed to arrive for the planned information literacy session at Hillside Library. The day before, the author had watched the librarians work with a group of 10 learners giving them quiz-like questions to be answered using the library's reference collection. They then were to bring 10 more whom they would instruct and these 10 children would tomorrow bring 10 more - and so on until the whole Grade had come. On the non-arrival of the group of children, Naledi Matolo (pseudonym), the Hillside Librarian, was despatched to fetch the children but the project soon fizzled out. Later that week the Woodsville Librarian - disappointed at the failure of the teachers to support the plan - asked plaintively, "Don't they know how important it is?”

The author's interviews with the principals and educators in the schools were aimed at answering her question. And the failure provoked several other questions for the author which became a preoccupation in the weeks to come. One set of questions concerns school and public library relationships. Why had the class not turned up? What, in the relationship between the school and the public library, might explain the failure? Had the same information literacy intervention with Bergsig Primary Grade Seven learners been the success Tara claimed? If so, how had it differed from the one planned for Hillside? 


\section{The Woodsville educators' perceptions of the public library}

The Table below provides a summary of the responses to some of the questions put to 23 Grade 7 and 8 educators (about 90\% of the teachers involved in these grades) - trying to find an answer to the librarian's question. The educators appear to acknowledge positively the role of the public library in the new curriculum; yet they also are revealed as having very little to do with it. The accompanying open-ended questions might throw light on the contradiction evident in these figures.

\begin{tabular}{|c|c|c|c|}
\hline Question & Yes & No & \\
\hline $\begin{array}{l}\text { Do you think Curriculum } 2005 \text { [the South } \\
\text { African curriculum introduced in the late } \\
\text { 1990s] has increased the use of public } \\
\text { libraries by school learners? }\end{array}$ & 22 & 1 & \\
\hline $\begin{array}{l}\text { [In your recent project] did you suggest to } \\
\text { your learners that they use the public } \\
\text { library? }\end{array}$ & 7 & 12 & \\
\hline $\begin{array}{l}\text { Did you discuss the project with the public } \\
\text { library staff before you set it? }\end{array}$ & 2 & 17 & \\
\hline $\begin{array}{l}\text { In planning your class assignments do you } \\
\text { ever consult or communicate with the public } \\
\text { library staff? }\end{array}$ & 4 & 19 & \\
\hline $\begin{array}{l}\text { Do you think that the public library has a } \\
\text { role to play in the educational programme of } \\
\text { your school? }\end{array}$ & 21 & 2 & \\
\hline $\begin{array}{l}\text { Who, in your opinion, should teach } \\
\text { information skills to school learners? }\end{array}$ & $\begin{array}{l}\text { School } \\
1\end{array}$ & $\begin{array}{l}\text { Public } \\
\text { library } \\
0\end{array}$ & $\begin{array}{l}\text { Both } \\
20\end{array}$ \\
\hline
\end{tabular}

The educators are unanimous that the new South African curriculum means that children need more resources and more access to libraries than before.

Responses to other questions show an awareness of the challenges of teaching diverse learners groups who have unequal access to learning resources at home. However, observations in the course of the case study and interviews with the public library staff show that such comment need not imply close working relationships with the two public libraries in Woodsville. For example, there was little evidence of communication between educators and the libraries - despite the regular overtures from the public libraries that their staff reported during the study. 
Most educators explain their positive reply to the first question in the table in rather theoretical language, reminiscent of that in the Revised National Curriculum Statement (South Africa. Department of Education, 2002). They thus talk of "independent research", "learner-centredness", "facilitating learning". One of the Hillside Primary educators acknowledges a possible gap between what educators are "supposed to" do and their classroom behaviour, when he says:

We used to impart knowledge to the kids. These days we engage learners in gathering information. We are supposed to. We might not be adjusted yet as educators.

A later question asks educators to describe their relationship with the Woodsville public libraries. Nine claim to have a "good" relationship. However, three of these nine admit that their knowledge of the library is not direct - they have witnessed the service their children receive or have heard of it from their learners. Eleven reply that they have no relationship or contact with either library, including six out of the eight respondents in the Hillside schools. Two Hillside High School educators phrase their answer to this question in an ambiguous phrase, "I ignore it". The word "ignore" seemed to be carefully chosen and perhaps implies a disdain for the library. And indeed, the Hillside teachers' responses include several critical comments on the mediocrity of Hillside Library, which is clearly perceived to be inferior to down-town Woodsville Library.

Their comments also suggest that they do not necessarily see librarians as partners in the educational programme. The words below of the Hillside Primary teacher, whose class had failed to turn up at Hillside Library a few days earlier, might throw light on the failure of the information literacy intervention. His lack of trust is clear in his comment on the initiative:

I don't think it's wise to send them over there without you every time. First I think, number one, the lady over there needed to have a particular partner in the school to work with. I don't think the people working over there in the library they shouldn't just sit back and expect the, especially the young learners, to use the library. I think learners should know - if the teacher is not there, they do have someone there who is acting as the teacher.

His words show how far the Hillside librarian is from being regarded as a partner in the curriculum.

Evidence of a certain obtuseness with regard to libraries might be found in responses to other questions that ask teachers to elaborate on their view of the role of the public library in the educational programme of their school. The 19 
educators who are recorded in the table above as never consulting the public library in planning their assignments seem surprised at the question. Their explanations are instructive, for example:

It never crossed my mind.

I never thought about it.

I've never needed it.

I've never involved them. There's no reason to.

The gulf between public library and school is illuminated in the words of one of the Hillside High School teachers, when she refers to a situation that infuriates the public library staff: "If the first person comes - the public library staff pick up which project we're doing. After the first three or four children, they know and help us and put books aside. They help us.”

As shown in the table above, 21 respondents gave positive responses when asked if they thought the public library had a role in the educational programme of their schools. But a perusal of their accompanying comments reveals rather limited views of the role. Most see it merely in terms of supplementing the resources of the school. It is the place where children go to "fetch" information. Thus:

When we teach the kids they must then go and get resources.

They supply learners with information.

They have stuff; they have things available. They put them out on tables.

There are only four replies which allow a larger role for the public library - in the learning of their pupils rather then the above "putting out" of materials. On the whole, it seems that the Woodsville educators lack cognizance of the demands of information seeking in the library. They see it as a warehouse where librarians hand over information on demand - so why would they need to consult with library staff in planning their work?

A possible explanation for the educators' lack of cognizance of libraries might lie in their backgrounds - as research in other contexts has suggested (Roberson, Applin and Schweinle, 2004). The interviews revealed a marked divide between the white teachers, who were brought up with books in the home and access to libraries, and the black teachers, who had few books at home, whose schools did not have libraries and whose neighbourhoods rarely had public libraries. For almost all of the black teachers, their first experience of libraries was at their teacher training colleges, where many of them, in common with their white colleagues, did "Library" - a course intended to teach them how to administer a school library. Only two black respondents remember being told stories by relatives and none of the black respondents were read to by parents, who were, most report, lacking in formal education. Two black teachers report 
that their parents were school principals but even they had only study books in their homes.

The educators' childhoods might well affect their present reading habits and attitudes to libraries. As Pretorius and Machet point out in their study of literacy education in schools in KwaZulu Natal, literacy behaviours are "socio-culturally constructed" (2004:59). In the Woodsville study, almost all the white teachers claim to read as a leisure pursuit; with several having special interests such as biography and adventure. A few of them buy books - at the excellent secondhand book shop in Woodsville or at book shops when they visit larger towns or via the Internet. Otherwise they rely on family gifts and loans. For leisure reading, the black teachers, except for one, read newspapers and magazines. They buy books only for study purposes. One young mother betrays her view of reading as a serious business, when she talks of reading to her four year old daughter, "It's hard to sit her down so that she can concentrate".

Examination of the educators' descriptions of information literacy and project work throws further light on their views of libraries. As mentioned earlier, Mpumalanga public librarians see use of the library as a crucial attribute of information literacy. However, in answering the same question, none of the educators mention the word "library". Most talk more generally of knowing how to find information and make no connection between that competency and the role of a library. Of course the comparison is not statistically reliable - the 57 librarians being a sample of Mpumalanga Province's public library staff involved in information literacy education and the 23 Woodsville educators coming from only seven schools in one small town. However, the differences point to an area for further corroborative research. Moreover, in their responses to the questions that probe their approaches to project work, most of the Woodsville educators underestimate the challenges of the early phases, when the problem is identified and meaningful questions formulated. Very few show awareness of the crucial early phases where learners have to negotiate an understanding of their task through preliminary background reading and discussion (Kuhlthau, 2004). This might explain the under-preparedness of school learners for their information seeking in the Woodsville libraries. Time and again, public library staff were observed struggling to help learners who cannot articulate what they need. They often have to explain assignments to learners - who, because they lack information-seeking strategies and also perhaps because of their weak English, just do not understand what they need to do. It seems that what they think they need is a page to copy. 


\section{Conclusion}

On the whole, it seems that the answer to the Woodsville Librarian's question, cited earlier, is "No". The Woodsville educators do not seem to understand the importance of the library in the information seeking needs of their learners. However their "obtuseness" must be understood in the light of their constricted views of the demands of school projects and assignments and their conception of the public library as a place where information is "fetched". Information is thus "something" that is stored and given out - rather than the subjective sensemaking process that research in cognitive information science and in information literacy has shown it to be (Kuhlthau 2004).

Paradoxically, the limited conceptions of the educators might recall those of public librarians, as hinted earlier. The first phase of the study found public librarians' conceptions of information literacy also to be rather limited, revealing a preoccupation with finding sources in the library. On the whole, they see their role to be the handing out of information rather than helping children with the cognitive demands of their assignments, although a nascent sense of the inadequacy of their current approaches is identified.

The Woodsville Librarian's question, “Don't they know how important it is?”, thus generates another one. What is the "it" in her question? The Librarian assumes that the "it" is self-explanatory. Perhaps, her own conceptions of information literacy and information literacy education also require expanding if the real needs of school learners are to be met. The author suggests that the limited vision of the public librarians in the study prevents them from seeking out a more dynamic role in addressing the needs of their school users by involving themselves in the earlier phases of project work. The reality is that neither public librarians nor teachers see librarians to be partners in the learning curriculum. How a more dynamic role in the context of the public library might be achieved is a topic for another article; but the first step must surely be recognition of its vital role in curricular change in this country.

\section{References}

American Association of School Librarians and Association for Educational Communications and Technology. 1998. Information power: building partnerships for learning: information literacy standards for student learning. Chicago: American Library Association. 
Australian School Library Association, Australian Library and Information Association. 2001. Learning for the future: developing information services in schools. $2^{\text {nd }}$ ed. Carlton, South Victoria: Curriculum Corporation.

Borman, M. 1995. Educational resources and teachers' resource centres. Cape Town: Western Cape Education Department.

Bot, M. 2005. School education in South Africa: tracking change over ten years. Edusource data news 48: 1-15.

Brown, J. 1999. Changing teaching practice to meet current expectations. In Haycock, K. (ed.) Foundations for effective school library media programs. Englewood, Colo: Libraries Unlimited. pp. 175-182.

Bundy, A. 2002. Essential connections: school and public libraries for lifelong learning. Australian library journal 51(1): 47-70.

Capra, F. 2003. The hidden connections: a science for sustainable living. London: Flamingo.

Clyde, A. 2002. An instructional role for librarians: an overview and content analysis of job advertisements. Australian academic and research libraries 3: 150-166.

Doiron, R. 1999. Curriculum encounters of the third kind: teachers and teacherlibrarians exploring curriculum potential. In Haycock, K. (ed.) 1999.

Foundations for effective school library media programs. Englewood, Colo: Libraries Unlimited. pp. 155-156.

Fullan, M.G. 1991. The new meaning of educational change. 2nd ed. London: Cassell.

Hara, K. 1999. Teachers' attitudes toward information skills instruction. Education libraries journal 42(2): 5-13.

Hart, G. 1999. Project work as a vehicle for information literacy education in disadvantaged schools. An ethnographic field study of Grade Seven project work in a primary school in Cape Town. M Ed (LIS) thesis. Cape Town, University of Cape Town. 
Hart, G. 2000. Project work as a vehicle for information literacy education in a circuit of South African schools. Paper delivered at 66th IFLA Council and General Conference Jerusalem, Israel, 13-18 August. IFLANET. http://www.ifla.org/IV/ifla66/papers/074-133e.htm. Accessed: 24/3/2005.

Hart, G. 2003. Public libraries stepping into the gap? A study of school learners' use of libraries in a disadvantaged community in Cape Town. In Zinn, S., Hart G., and Howe, E. (eds.) IASL reports 2003: school libraries breaking down barriers. Selected papers from the 32nd Annual Conference of the International Association of School Librarianship and the 7th International Forum on Research in School Librarianship. Durban, South Africa, 7-11 July 2003. Seattle: IASL pp. 71-83.

Hart, G. 2004. Public libraries in South Africa: agents or victims of educational change? South African journal of libraries and information science 70 (2): 110121.

Henri, J. 2001. Thinking and informing: a reality check on class teachers and teacher-librarians. In Hughes, P. and Selby, L. (eds.) Inspiring connections: learning, libraries and the literacies. Proceedings of the $30^{\text {th }}$ Annual Conference of the International Association of School Librarianship. Seattle: International Association of School Librarianship pp 119-128.

Karlsson, J. 2003. The politics of making a new space for school libraries in South Africa. In Zinn, S., Hart, G. and Howe, E. (eds.) IASL reports 2003: school libraries breaking down barriers. Selected papers from the 32nd Annual Conference of the International Association of School Librarianship and the 7th International Forum on Research in School Librarianship. Durban, South Africa, 7-11 July 2003. Seattle: IASL. pp. 1-9.

Kuhlthau, C.C. 1993. Implementing a process approach to information skills: a study identifying indicators of success in library media programs. School library media quarterly 21 (2): 11-18.

Kuhlthau, C.C. 2000. The information search process: a search for meaning rather than answers. Library and information science 43: 35-42.

Kuhlthau, C.C. 2004. Seeking meaning: a process approach to library and information services. 2nd ed. Westport, Conn: Ablex.

Leach, A. 1998. An overview of the public library sector in South Africa post 1994. Innovation 16: 3-19. 
Lombo, S. 2002. The relationship between OBE, learner support materials and a school library. In Education Library Information and Technology Services. Ghost Libraries and Curriculum 2005: [proceedings of] 1st Annual Provincial Conference, 11-13 July. Durban: ELITS, Department of Education and Culture KwaZulu Natal pp. 3-6.

Lor, P.J. 1998. Memorandum on the state of libraries in South Africa, March 1998. LIASA Newsletter 2(1): 7-12.

Maepa, E. and Mhinga, R. 2003. Integrating a community library into the teaching and learning programme of local schools: experiences from Seshego Community Library, South Africa. In Zinn, S., Hart, G., and Howe, E. (eds.) IASL reports 2003: school libraries breaking down barriers. Selected papers from the 32nd Annual Conference of the International Association of School Librarianship and the 7th International Forum on Research in School Librarianship. Durban, South Africa, 7-11 July 2003. Seattle: IASL. pp. 270279.

Marsh, C. and Morris, P. 1991. Curriculum development in East Asia. London: Falmer Press.

McMillan, D. 2001. Taking up the challenge: how can public libraries help develop information literate children? APLIS, 14(1): 4-13.

Metcalfe, L. 1994. Managing resource-based learning. Stimulus 2(1): 1-2.

Peacock, J. 2001. Teaching skills for teaching librarians: postcards from the edge of the educational paradigm. Australian academic and research libraries 32(1): 26-42.

Pretorius, E. J. and Machet, M.P. 2004. The socio-educational context of literacy accomplishment in disadvantaged schools: lessons for reading in the early primary years. Journal of language teaching 38(1): 45-61.

Roberson, T.J., Applin, M.B. and Schweinle, W. 2004. School libraries' impact upon student achievement and school professionals' attitudes that influence use of library programs. Educational research quarterly 10(1): 45-52.

South Africa. Department of Education. 1999. South African school library survey 1999. National report. Pretoria: Department of Education and Human Sciences Research Council. 
South Africa. Department of Education. 2002. Revised national curriculum statement. June. http://education.pwv.gov.za/ Accessed: 15/6/2005.

Todd, R. 1995a. Information literacy: a sensemaking approach to learning. In Booker, D. (ed.) The learning link: information literacy in practice. Adelaide: Auslib Press: pp.17-26.

Todd, R. 1995b. Integrated information skills instruction: does it make a difference? School library media quarterly 23(2): 133-138.

Todd, R and Kulthau, C.C. 2005. Student learning through Ohio School libraries, Part 2: Faculty perceptions of effective school libraries. School libraries worldwide 11(1): 89-110.

Turner, P. 1991. Information skills and instructional consulting: a synergy? School library media quarterly 20(1): 13-18.

Zinn, S. 2001. School libraries in South Africa - a progress report 2001. Paper presented at the IFLA/Arab Conference on Public and School Librarianship in Rabat, Morocco September 19-22. Unpublished paper. 